\title{
INTRA- AND INTER-PERSONAL FACTORS OF PSYCHOSOCIAL STATUS IN SLOVENIAN MILITARY PERSONNEL WITH REGARD TO THEIR TRAUMATIC EVENT EXPERIENCE OSEBNI IN MEDOSEBNI DEJAVNIKI PSIHOSOCIALNEGA STATUSA PRI OSEBJU SLOVENSKE VOJSKE GLEDE NA IZKUŠNJO TRAVMATSKEGA DOGODKA \\ Polona Selič ${ }^{1}$, Maša Serec ${ }^{1}$, Davorina Petek ${ }^{1}$, Maja Rus - Makovec ${ }^{2}$
}

Prispelo: 29. 11. 2010 - Sprejeto: 31. 3. 2011

Original scientific article

UDC 159.944.4:355.08(497.4)

\begin{abstract}
Problem: The main objectives of this study were to identify differences in the psychosocial status of military personnel who had and who had no traumatic event experience, and to screen for potential mental health vulnerability related to post-traumatic stress.

Methods: 390 military personnel were included in the study, with 103 of them reporting traumatic event experience. The Mini-International Neuropsychiatric Interview Screening for Post-Traumatic Stress Disorder, the CAGE instrument, the Eysenck Personality Scales, the Folkman-Lazarus Ways of Coping Questionnaire, the Rosenberg Self-Esteem scale and self-evaluative questions about important relationships were administered.

Results: The respondents who reported traumatic event experience (TEE) also reported a significantly higher frequency of other stressful events, a significantly more frequent past history of depression (16.5\% of respondents with TEE and $6.2 \%$ of respondents without TEE) and significantly higher risky alcohol drinking; the latter, however, is not higher than the estimate for the total Slovenian population (10.7\% of respondents with TEE and $2.7 \%$ of participants without TEE). Respondents with TEE smoke less frequently than respondents who reported no TEE (46.6 \% vs. $60.1 \%$ ), and more often rely on self in stressful situations. There was no significant difference between the respondents with reported TEE and those without TEE in their personality traits, coping styles, and self-esteem, or in the majority of job- and family-related factors. No difference was found between male and female personnel as concerns intra-personal factors and in stress- related behaviour.

Conclusions: Intra-personal factors (personality, coping styles, and self-esteem) of military personnel indicate good personal potential for resilience. Stress-related substance (ab)use, especially smoking rates well above the Slovenian average, need further attention. Professional support needs to be promoted, especially in female personnel, who are less likely than men to seek social support in times of stress, and in military personnel exposed to cumulative stressors.
\end{abstract}

Key words: trauma, coping, psychosocial status, military personnel, gender

\section{Izvleček}

Izvirni znanstveni članek UDK 159.944.4:355.08(497.4)

Problem: S študijo smo želeli opredeliti razlike v psihosocialnem statusu vojaškega osebja glede na morebitni travmatski stresni dogodek in opraviti osnovno presejanje glede duševne ranljivosti, ki jo je povzročila travmatska izkušnja.

Metoda: V študijo smo vključili 390 pripadnikov slovenske vojske, od katerih so 103 poročali o travmatski izkušnji. Uporabili smo naslednje vprašalnike: vprašalnik MINI (angl. The Mini-International Neuropsychiatric Interview screening) - diagnostična merila za posttravmatsko stresno motnjo, vprašalnik CAGE za presejanje tveganega 
uživanja alkohola, Eysenckove osebnostne lestvice, Folkman-Lazarusovo lestvico glede načinov spoprijemanja s stresom, Rosenbergovo lestvico samospoštovanja in vprašanja za samoovrednotenje pomembnih navezovalnih odnosov.

Rezultati: Ugotavljamo, da so pri udeležencih z izkušnjo travmatskega dogodka značilno pogosteje prisotni drugi stresni dogodki, izkušnje depresije v preteklosti (16,5 \% pri udeležencih z izkušnjo travme in 6,2 \% pri udeležencih brez izkušnje travme) in tvegano uživanje alkohola, ki pa ni večje od ocene za slovensko populacijo $(10,7 \%$ tveganega uživanja alkohola pri udeležencih z izkušnjo travme in 2,7 \% pri udeležencih brez nje). Udeleženci z izkušnjo travme so kadili v značilno manjši meri (46,6 \% oz. 60,1 \%) in se tudi bolj zanesejo nase v stresnih okoliščinah. Udeleženci študije z izkušnjo travmatskega dogodka se niso pomembno razlikovali od udeležencev, ki niso doživeli travmatskega dogodka, glede osebnostnih dejavnikov, obvladovalnih stilov, ravni samospoštovanja in glede večine dejavnikov, povezanih z delovnim mestom in s pomembnimi izkušnjami iz otroštva. Ženske se niso pomembno razlikovale od moških glede intrapsihičnih dejavnikov in s stresom povezanega vedenja.

Zaključek: Intrapsihični dejavniki (osebnostne značilnosti, obvladovalni stili, raven samospoštovanja) pri članih slovenske vojske nakazujejo precejšnjo psihološko odpornost. V prihodnjih študijah pa se bomo morali posvetiti zlasti s stresom povezani tvegani rabi psihotropnih snovi, posebej kajenju, ki se pojavlja izrazito pogosteje od slovenskega povprečja. Predvsem pripadnice slovenske vojske in osebje, ki je podvrženo pogostim stresnim dejavnikom, pa moramo seznaniti z možnostjo strokovne pomoči, saj je raziskava pokazala, da ti v veliko manjši meri poiščejo kakršno koli obliko socialne podpore.

Ključne besede: travma, obvladovanje, psihosocialni status, vojaško osebje, spol

\section{Introduction}

Stressful life events, lack of social support and depression are thought to influence risks for poor health status $(1,2)$. On the other hand, social support, disclosure of trauma and social acknowledgement are relevant interpersonal factors in trauma recovery (3, 4). Several functional and defensive strategies to cope with trauma-like experience are associated with social support and relationship with important others (5). Lack of social support is one of the strongest predictors of post-traumatic stress disorder (PTSD), although the perception of having social support does not necessarily promote positive outcomes (6). Stressful life events have been shown to exacerbate PTSD symptoms (7). Survival analysis in a community sample of 1803 young adults revealed that the risk of PTSD is associated with retrospectively reported adverse experiences that occurred in the years prior to the focal traumatic event (8). The capacity for resilience is also related to additional life stressors (9). Subclinical aspects of PTSD are often overlooked (10) and can be masked by depression, anxiety and alcohol abuse (11).

While the symptom profile and underlying neurobiology of PTSD have received considerable attention in the literature, less attention has been paid to the interpersonal dynamics and social isolation associated with the disorder. A study of the relational dynamics of combat veterans with PTSD suggests that they exhibit characteristically avoidant attachment styles.
Attachment avoidance and ambivalent attachmenthave been shown to be associated with a greater number of PTSD symptoms (14). Adult attachment style and PTSD symptomatology were investigated in 107 former prisoners of war (15). Those with secure attachment styles scored significantly lower on measures of PTSD than did those with insecure styles; attachment style was a stronger predictor of PTSD symptom intensity than was trauma severity. Hazen and Shaver (12) proposed a model of critical nature of primary attachment bonds. More recent theorists, however, have begun to argue that the individual's perception of their attachment relationships of early years is more critical than the occurrence of true childhood attachment-related events (13).

It was found that pre-war risk factors differed between women and men (16). In women, instability within the primary family had the largest influence on PTSD; an early trauma history was also strongly associated with PTSD. In men, PTSD was predicted by family instability, childhood antisocial behaviour, and a younger age of entry into the war; an early trauma history was also directly associated with PTSD. An early trauma history also interacted with the war-zone level of stress to increase PTSD symptoms for male veterans exposed to intense combat. Social support, hardiness, and additional negative life events following Vietnam affected both men's and women's resilience and recovery (17).

Schnurr et al. (18) examined risk factors for PTSD in veterans, and found that pre-military factors included 
family instability, and severe punishment, antisocial behaviour and depression during childhood, while military factors included recent stressful life events, post-Vietnam trauma, and depression. The premilitary risk factor for PTSD maintenance was severe punishment during childhood; post-military risk factors included recent stressful life events. Factors preventing the development of PTSD included higher socioeconomic status, a positive paternal relationship and higher education before entering the military. There were no preventive factors while in the military, but after leaving the forces, social support at homecoming and current social support were found to have a preventive function.

The main aims of our study were to identify the differences in psychosocial status of military personnel who had and those who had no traumatic event experience (TEE), and to screen for potential posttraumatic stress-related mental health vulnerability. We were especially interested in how perceptions of interpersonal factors (perceptions of primary family and of important social relationships) and intra-personal factors (personality, coping styles, and self-esteem) differ with regard to TEE. One of the goals was also to identify differences in intimate and social relationships and stress-related behaviour between female and male military personnel.

We hypothesized that the respondents who reported TEE differed significantly from those without reported TEE in job- and employment-related variables, risk of mental problems (yes/no questions) and addictive behaviour; different types of childhood experiences; perceived social support from social resources; particular personality traits and coping styles; and level of self esteem. The null hypothesis was that there are no significant differences in dependent variables with regard to gender.

\section{Methods}

\subsection{Subjects}

At the beginning of 2008, the professional Slovenian Army numbered 5908 military personnel. All the soldiers billeted in three barracks in the central part of Slovenia were invited to participate in the study; a total of 448 voluntarily agreed to participate. Of these, 390 returned completed questionnaires (87\% response rate); 87.7 $\%$ were men, a share comparable to that for the total population of the Slovenian Army $(86.19 \%$ men).
At first the structure of the sample (gender and rank) was intended to represent the Army population. However, the proportion of soldiers who were willing to participate was larger than in the general Army population and the proportion of officers was smaller (soldiers: $60.0 \%$ versus: $47.2 \%$; non-commissioned officers $25.1 \%$ versus $30.0 \%$ and officers $14.9 \%$ versus $22.8 \%$ ). A total of 287 respondents (age $\mathrm{M}=30.54, \mathrm{SD}=7,64$ ) did not reported TEE and 103 did (age $M=31,25, S D=$ $7,54)$. There was no significant age-specific difference between the respondent groups $(p=0.420)$.

The study was approved by the National Ethics Committee of the Republic of Slovenia on 24 October 2006.

\subsection{Instruments and measures}

The following instruments were used: a questionnaire about demographic and job/employment status, including questions about the number of deaths of important others, and the number of stressful events experienced within the past year and previously in the adult life (e.g. serious difficulties in marital and parental relationships, serious financial problems, divorce and severe mental or somatic diseases of important others). Screening for TEE and the risk of recent and past history of depression was assessed by relevant screening questions from The Mini-International Neuropsychiatric Interview (M.I.N.I.) (19) (e.g. "Have you ever experienced, seen or were confronted by an extremely traumatic event, in which death occurred, or the possibility of your or others' death or very serious injury was present?"). The CAGE instrument was used to screen for alcohol abuse (20). The availability of social support was assessed by multiple choice questions, like:" In times of serious adversity or stress, do you seek or rely on the support of the following people: partner, other family members, friends, co-workers, professionals?" Childhood family relationships were assessed by questions about perceptions of parental availability, stability of circumstances, perceptions of safety, experience of abusive family relationships during childhood, and availability of a supportive person or people outside the family. The Eysenck Personality Scales (21), the Folkman-Lazarus Ways of Coping Questionnaire (22) and the Rosenberg Self-Esteem scale (23) were administered as intra-psychical variables of psychosocial adjustment.

Comparisons of the characteristics of two groups (TEE yes/no; gender) were tested using the chi-square test, and the Mann Whitney nonparametric test for two independent samples. The one-sample Kolmogorov Smirnov nonparametric $(\mathrm{K}-\mathrm{S})$ test showed that the 
distribution of central dependent variables significantly differed from the norm, which is why nonparametric tests were mostly used. Statistical analyses were carried out using the SPSS statistical package, version 17.0 (SPSS Inc., Chicago, IL, USA).

\section{Results}

Differences in the number of deaths of important others, and in experience of recent (in the last year) and previous (during adult life) stressful events are shown in Table 1.

Table 1. Mann Whitney test of differences in the mean ranks of the chosen dependent variables regarding reported and unreported TEE.

Tabela 1. Mann-Whitneyev test razlik v aritmetičnih sredinah pri izbranih odvisnih spremenljivkah glede na prisotnost ali odsotnost travmatskega stresnega dogodka.

\begin{tabular}{|l|l|l|l|l|l|l|}
\hline $\begin{array}{l}\text { Dependent variables } \\
\text { Odvisne spremenljivke }\end{array}$ & $\begin{array}{l}\text { Trauma YES } \\
\text { travma DA } \\
\text { Mean (SD) } \\
\text { poprečje (SD) }\end{array}$ & $\begin{array}{l}\text { Trauma YES } \\
\text { travma DA } \\
\text { Mean ranks } \\
\text { poprečni rangi }\end{array}$ & $\begin{array}{l}\text { Trauma NO } \\
\text { travma NE } \\
\text { Mean (SD) } \\
\text { poprečni rangi }\end{array}$ & $\begin{array}{l}\text { Trauma NO } \\
\text { travma NE } \\
\text { Mean ranks } \\
\text { poprečni rangi }\end{array}$ & Z & P value \\
\hline $\begin{array}{l}\text { No. of deaths of } \\
\text { important others } \\
\text { Število umrlih } \\
\text { pomembnih drugih }\end{array}$ & $0.72(1.13)$ & 216.97 & $0.38(0.78)$ & 187.79 & -2.81 & 0.005 \\
\hline $\begin{array}{l}\text { No. of recent stressful } \\
\text { events } \\
\text { Število nedavnih } \\
\text { stresnih dogodkov }\end{array}$ & $0.83(1.15)$ & 228.59 & $0.36(0.78)$ & 183.63 & -4.32 & $<0.001$ \\
\hline $\begin{array}{l}\text { No. of stressful events } \\
\text { in the past } \\
\text { Število stresnih } \\
\text { dogodkov v preteklosti }\end{array}$ & $1.35(1.38)$ & 245.94 & $0.57(0.95)$ & 177.40 & -5.90 & $<0.001$ \\
\hline
\end{tabular}

Note: number of respondents without reported trauma: $n=287$; with reported trauma: $n=103$.

Table 2. Chi-square test of probability differences in job-and employment-related variables regarding reported and unreported TEE.

Tabela 2. Rezultati testa hi-kvadrat pri obravnavanih spremenljivkah glede prisotnosti oz. odsotnosti travmatskega stresnega dogodka.

\begin{tabular}{|l|l|l|l|l|}
\hline $\begin{array}{l}\text { Job and employment related variables } \\
\text { Spremenljivke za delo in zaposlitev }\end{array}$ & $\begin{array}{l}\mathrm{N} \\
\text { total }\end{array}$ & $\chi^{2}$ & df & $\mathrm{p}$ \\
\hline $\begin{array}{l}\text { Gender (male/female) } \\
\text { Spol(ž/m) }\end{array}$ & 390 & 4.88 & 1 & 0.027 \\
\hline $\begin{array}{l}\text { Rank (three ranks) } \\
\text { Rang (trije rangi) }\end{array}$ & 379 & 0.48 & 2 & 0.787 \\
\hline $\begin{array}{l}\text { Higher education obtained in the army (yes/no) } \\
\text { Izobrazba, pridobljena v vojski (da/ne) }\end{array}$ & 389 & 5.85 & 1 & 0.016 \\
\hline $\begin{array}{l}\text { Additional necessary skills obtained in the Army (yes/no) } \\
\text { Dodatna potrebna znanja pridobljena v vojski (da/ne) }\end{array}$ & 389 & 0.28 & 1 & 0.592 \\
\hline $\begin{array}{l}\text { Wished-for job (yes/no) } \\
\text { Željena služba (da/ne) }\end{array}$ & 384 & 0.04 & 1 & 0.835 \\
\hline $\begin{array}{l}\text { Unsuccessful promotion (yes/no) } \\
\text { Neuspešno napredovanje (da/ne) }\end{array}$ & 387 & 3.14 & 1 & 0.076 \\
\hline $\begin{array}{l}\text { Successful promotion (yes/no) } \\
\text { Uspešno napredovanje (da/ne) }\end{array}$ & 388 & 0.03 & 1 & 0.861 \\
\hline
\end{tabular}

Note: Number of cells with expected count of less than five nowhere exceeds the limit of $20 \%$. 
Table 3. Chi-square tests of probability differences in screening for risk of mental problems and addictive behaviour with regard to TEE and gender.

Tabela 3. Rezultati testov hi-kvadrat pri presejanju glede razvoja potencialnih duševnih težav in odvisnega vedenja glede na travmatski stresni dogodek in spol.

\begin{tabular}{|c|c|c|c|c|c|c|c|c|}
\hline \multirow{2}{*}{$\begin{array}{l} \\
\text { Screening (yes/no) } \\
\text { Presejanje } \\
\text { (da/ne) }\end{array}$} & \multicolumn{4}{|c|}{$\begin{array}{l}\text { TEE (Yes: } n=103, \text { No: } n=287 \text { ) } \\
\text { TEE (da: } n=103, n e: n=287\end{array}$} & \multicolumn{4}{|c|}{$\begin{array}{l}\text { Gender (male: } n=342 \text {, female: } n=48 \text { ) } \\
\text { Spol (moški: } n=342 \text {, ženske: } n=48 \text { ) }\end{array}$} \\
\hline & $N$ & $\chi^{2}$ & df & $p$ & $\mathrm{n}$ & $\chi^{2}$ & df & $P$ \\
\hline $\begin{array}{l}\text { Depression now } \\
\text { Depresija - zdaj }\end{array}$ & 390 & 2.72 & 1 & 0.099 & 390 & 0.06 & 1 & 0.805 \\
\hline $\begin{array}{l}\text { Depression before } \\
\text { Depresija - prej }\end{array}$ & 390 & 9.71 & 1 & 0.002 & 390 & 2.10 & 1 & 0.147 \\
\hline $\begin{array}{l}\text { Alcohol abuse } \\
\text { Zloraba alkohola }\end{array}$ & 390 & 10.18 & 1 & 0.001 & 390 & 0.05 & 1 & 0.809 \\
\hline $\begin{array}{l}\text { Smoking } \\
\text { Kajenje }\end{array}$ & 384 & 7.84 & 2 & 0.020 & 384 & 0.34 & 2 & 0.843 \\
\hline
\end{tabular}

Note: Number of cells with expected count of less than five nowhere exceeds the limit of $20 \%$.

We found that $24.6 \%$ of male and $39.6 \%$ of female respondents reported TEE; $24 \%$ of military personnel without TEE and $38.2 \%$ with TEE had obtained higher education during their time in the Army.

A total of $24.2 \%$ of personnel, grouped as 'risk of past depression - no', and $48.6 \%$ of those screened as 'risk of past depression - yes', reported TEE $(16.5 \%$ of past depression in respondents with TEE, and $6.2 \%$ in respondents without TEE). TEE was reported by $57.9 \%$ of at-risk alcohol drinkers, and in $24.8 \%$ of non-risk alcohol users $(10.7 \%$ of risky drinking in respondents with TEE and $2.7 \%$ in those without TEE). However, the frequency of smoking is lower and the frequency of smoking cessation higher in respondents with TEE. As many as $46.6 \%$ of respondents with TEE are smokers (vs. $60.1 \%$ of respondents without TEE), $38.8 \%$ are non-smokers (vs. $32.7 \%$ of respondents without TEE), and $14.5 \%$ of them reported they quit smoking (vs. $7.1 \%$ of respondents without TEE).

The differences in the perceptions of own childhood experience (family, self) with regard to TEE and gender are presented in Table 4: $25.2 \%$ of those who reported no behavioural problems in childhood, and $41.9 \%$ of those who did, reported TEE; $17.8 \%$ of those who evaluated themselves as without any special talents in childhood, and $31.8 \%$ of those who evaluated themselves as an especially talented child had TEE. $52.8 \%$ of men and $35.4 \%$ of women reported good experiences with adult authority outside the family in childhood.

Respondents who reported no TEE more frequently seek support from family members. The proportion of military personnel without TEE who would seek support from their partners in times of stress is $87.7 \%$ (87.3 $\%$ for support from other family members) and the share of their peers without TEE is $78.1 \%$ ( $78.7 \%$ for support from other family members); $71.9 \%$ of military personnel, both with and without TEE, said they would not seek professional help.

Female respondents are significantly less likely to seek social support; $3.4 \%$ of men responded they would not seek support from their family $(10.6 \%$ not from friends, $40 \%$ not from co-workers, $69.7 \%$ not from professionals), and $25.5 \%$ of women would reportedly not seek support from their family $(21.7 \%$ not from friends, $64.3 \%$ not from co-workers, $87.8 \%$ not from professionals). 
Table 4. Chi-square tests of probability differences in perceptions of own childhood experience (family, self) with regard to TEE and gender.

Tabela 4. Test hi-kvadrat za ugotavljanje razlik v zaznavanju izkušenj iz otroštva (družina, jaz) glede na TEE in spol.

\begin{tabular}{|c|c|c|c|c|c|c|c|c|}
\hline \multirow[b]{2}{*}{$\begin{array}{l}\text { Variables } \\
\text { Spremenljivke }\end{array}$} & \multicolumn{4}{|c|}{$\begin{array}{l}\text { TEE (yes: } n=103, \text { no: } n=287 \text { ) } \\
\text { TEE (da: } n=103, \text { no: } n=287 \text { ) }\end{array}$} & \multicolumn{4}{|c|}{$\begin{array}{l}\text { Gender (male: } n=342 \text {, female: } n=48) \\
\text { spol (moški: } n=342 \text {, ženske: } n=4 \text { 8) }\end{array}$} \\
\hline & $\mathrm{N}$ & $\chi^{2}$ & $d f$ & $p$ & $\mathrm{~N}$ & $\chi^{2}$ & df & $P$ \\
\hline $\begin{array}{l}\text { Living with both/one } \\
\text { parents or in foster care } \\
\text { Življenje z obema } \\
\text { staršema, z enim staršem, } \\
\text { ali v rejništvu }\end{array}$ & 386 & 0.98 & 2 & 0.610 & 386 & 1.45 & 2 & 0.484 \\
\hline $\begin{array}{l}\text { Enough safety in childhood } \\
\text { Dovolj varnosti v otroštvu }\end{array}$ & 390 & 1.85 & 2 & 0.395 & 390 & 3.29 & 2 & 0.192 \\
\hline $\begin{array}{l}\text { Stability } \\
\text { Stabilnost }\end{array}$ & 382 & 2.76 & 2 & 0.251 & 382 & 0.43 & 2 & 0.803 \\
\hline $\begin{array}{l}\text { Very good experience with } \\
\text { adult outside the family } \\
\text { Zelo dobre izkušnje z } \\
\text { odraslim izven družine }\end{array}$ & 389 & 0.33 & 2 & 0.848 & 389 & 10.25 & 2 & 0.006 \\
\hline $\begin{array}{l}\text { Type of abuse experience } \\
\text { in family } \\
\text { Vrsta zlorabe v družini }\end{array}$ & 387 & 1.28 & 2 & 0.526 & 387 & 4.92 & 2 & 0.085 \\
\hline $\begin{array}{l}\text { Child with behavioural } \\
\text { problems } \\
\text { Otrok z vedenjskimi } \\
\text { težavami }\end{array}$ & 388 & 4.09 & 1 & 0.043 & 388 & 0.01 & 1 & 0.925 \\
\hline $\begin{array}{l}\text { Especially talented as a } \\
\text { child } \\
\text { Zelo nadarjen kot otrok }\end{array}$ & 388 & 9.16 & 1 & 0.002 & 388 & 1.40 & 1 & 0.237 \\
\hline $\begin{array}{l}\text { Very anxious child } \\
\text { Zelo anksiozen otrok }\end{array}$ & 388 & 0.30 & 1 & 0.578 & 388 & 0.06 & 1 & 0.802 \\
\hline
\end{tabular}

Note: Number of cells with expected count of less than five nowhere exceeds the limit of $20 \%$. 
Table 5. Chi-square tests of probability differences in perceptions of social support in times of adversity/ stress with regard to TEE and gender.

Tabela 5. Hi-kvadrat test za ugotavljanje verjetnosti razlik v zaznavanju socialne pomoči v stiski/stresnih situacijah, glede na prisotnost travmatične izkušnje in spol.

\begin{tabular}{|c|c|c|c|c|c|c|c|c|}
\hline \multirow[b]{2}{*}{$\begin{array}{l}\text { Seek support from } \\
\text { (yes/no) } \\
\text { Iskanje pomoči (da/ne) }\end{array}$} & \multicolumn{4}{|c|}{$\begin{array}{l}\text { TEE } \\
(\text { yes } / \text { da } n=103, \text { no/ne }=287)\end{array}$} & \multicolumn{4}{|c|}{$\begin{array}{l}\text { Gender } \\
\text { Spol } \\
\text { (male: } n=342 \text {, female: } n=48 \text { ) } \\
\text { (moški: } n=342 \text {, ženske: } n=48 \text { ) }\end{array}$} \\
\hline & $\mathrm{n}$ & $\chi^{2}$ & df & $p$ & $\mathrm{n}$ & $\chi^{2}$ & df & $P$ \\
\hline $\begin{array}{l}\text { partner } \\
\text { partner }\end{array}$ & 367 & 5.31 & 1 & 0.021 & 367 & 3.54 & 1 & 0.060 \\
\hline $\begin{array}{l}\text { family } \\
\text { družina }\end{array}$ & 368 & 4.18 & 1 & 0.041 & 368 & 4.75 & 1 & 0.029 \\
\hline $\begin{array}{l}\text { friends } \\
\text { prijatelji }\end{array}$ & 366 & 0.31 & 1 & 0.573 & 366 & 4.69 & 1 & 0.030 \\
\hline $\begin{array}{l}\text { co-workers } \\
\text { sodelavci }\end{array}$ & 342 & 0.92 & 1 & 0.337 & 342 & 8.86 & 1 & 0.003 \\
\hline $\begin{array}{l}\text { professionals } \\
\text { strokovnjaki }\end{array}$ & 331 & 0.00 & 1 & 0.999 & 331 & 5.85 & 1 & 0.016 \\
\hline
\end{tabular}

Note: Number of cells with expected count of less than five nowhere exceeds the limit of $20 \%$. 
Table 6. Expression of personality traits, coping styles and level of self-esteem regarding the respondents with and without TEE.

Tabela 6. Izraženost osebnostnih značilnosti, strategij spoprijemanja s stresom in stopnje samospoštovanja pri sodelujočih, ki so doživeli travmatičen dogodek in tistih, ki te izkušnje niso imeli.

\begin{tabular}{|c|c|c|c|c|c|}
\hline & TEE & n & $\begin{array}{l}\text { mean rank } \\
\text { poprečje rangov }\end{array}$ & z & $p$ \\
\hline \multicolumn{6}{|l|}{$\begin{array}{l}\text { Personality traits } \\
\text { Osebnostne značilnosti }\end{array}$} \\
\hline \multirow{2}{*}{$\begin{array}{l}\text { Psychoticism } \\
\text { Psihoticizem }\end{array}$} & \begin{tabular}{|l|} 
No \\
ne
\end{tabular} & 287 & 193.58 & -0.565 & 0.572 \\
\hline & $\begin{array}{l}\text { Yes } \\
\text { da }\end{array}$ & 103 & 200.85 & & \\
\hline \multirow{2}{*}{$\begin{array}{l}\text { Extraversion } \\
\text { Ekstravertiranost }\end{array}$} & $\begin{array}{l}\text { No } \\
\text { ne }\end{array}$ & 287 & 191.22 & -1.255 & 0.209 \\
\hline & $\begin{array}{l}\text { Yes } \\
\text { da }\end{array}$ & 103 & 207.41 & & \\
\hline \multirow{2}{*}{$\begin{array}{l}\text { Neuroticism } \\
\text { Nevrotičnost }\end{array}$} & $\begin{array}{l}\text { No } \\
\text { ne }\end{array}$ & 287 & 191.71 & -1.112 & 0.266 \\
\hline & \begin{tabular}{|l}
$\begin{array}{l}\text { Yes } \\
\text { da }\end{array}$ \\
\end{tabular} & 103 & 206.07 & & \\
\hline \multirow{2}{*}{$\begin{array}{l}\text { Lie-scale } \\
\text { Lestvica laži }\end{array}$} & $\begin{array}{l}\text { No } \\
\text { ne }\end{array}$ & 287 & 201.58 & -1.784 & 0.075 \\
\hline & \begin{tabular}{|l|}
$\begin{array}{l}\text { Yes } \\
\text { da }\end{array}$ \\
\end{tabular} & 103 & 178.56 & & \\
\hline \multicolumn{6}{|l|}{$\begin{array}{l}\text { Coping } \\
\text { Spoprijemanje s stresom }\end{array}$} \\
\hline \multirow{2}{*}{$\begin{array}{l}\text { Confrontative coping } \\
\text { Soočanje }\end{array}$} & $\begin{array}{l}\text { No } \\
\text { ne }\end{array}$ & 287 & 195.75 & -0.222 & 0.824 \\
\hline & $\begin{array}{l}\text { Yes } \\
\text { da }\end{array}$ & 102 & 192.89 & & \\
\hline \multirow{2}{*}{$\begin{array}{l}\text { Distancing } \\
\text { Umik }\end{array}$} & $\begin{array}{l}\text { No } \\
\text { ne }\end{array}$ & 287 & 198.83 & -1.135 & 0.256 \\
\hline & \begin{tabular}{|l|}
$\begin{array}{l}\text { Yes } \\
\text { da }\end{array}$ \\
\end{tabular} & 102 & 184.21 & & \\
\hline \multirow{2}{*}{$\begin{array}{l}\text { Self-controlling } \\
\text { Samoobvladovanje }\end{array}$} & $\begin{array}{l}\text { No } \\
\text { ne }\end{array}$ & 287 & 194.58 & -0.123 & 0.902 \\
\hline & $\begin{array}{l}\begin{array}{l}\text { Yes } \\
\text { da }\end{array} \\
\end{array}$ & 102 & 196.17 & & \\
\hline \multirow{2}{*}{$\begin{array}{l}\text { Seeking social support } \\
\text { Iskanje socialne pomoči }\end{array}$} & $\begin{array}{l}\text { No } \\
\text { ne }\end{array}$ & 287 & 191.90 & -0.917 & 0.359 \\
\hline & \begin{tabular}{|l}
$\begin{array}{l}\text { Yes } \\
\text { da }\end{array}$ \\
\end{tabular} & 102 & 203.73 & & \\
\hline \multirow{2}{*}{$\begin{array}{l}\text { Accepting responsibility } \\
\text { Prevzemanje odgovornosti }\end{array}$} & $\begin{array}{l}\text { No } \\
\text { ne }\end{array}$ & 287 & 192.28 & -0.813 & 0.416 \\
\hline & $\begin{array}{l}\begin{array}{l}\text { Yes } \\
\text { da }\end{array} \\
\end{array}$ & 102 & 202.67 & & \\
\hline \multirow{2}{*}{$\begin{array}{l}\text { Escape-Avoidance } \\
\text { Beg-izogibanje }\end{array}$} & $\begin{array}{l}\text { No } \\
\text { ne }\end{array}$ & 287 & 200.21 & -1.540 & 0.124 \\
\hline & $\begin{array}{l}\text { Yes } \\
\text { da }\end{array}$ & 102 & 180.34 & & \\
\hline \multirow{2}{*}{$\begin{array}{l}\text { Planned Problem Solving } \\
\text { Načrtovano reševanje problemov }\end{array}$} & $\begin{array}{l}\text { No } \\
\text { ne }\end{array}$ & 287 & 192.74 & -0.670 & 0.503 \\
\hline & $\begin{array}{l}\begin{array}{l}\text { Yes } \\
\text { da }\end{array} \\
\end{array}$ & 102 & 201.37 & & \\
\hline \multirow{2}{*}{$\begin{array}{l}\text { Positive reappraisal } \\
\text { Pozitivna ponovna ocena }\end{array}$} & $\begin{array}{l}\text { No } \\
\text { ne }\end{array}$ & 287 & 195.41 & -0.122 & 0.903 \\
\hline & $\begin{array}{l}\text { Yes } \\
\text { da }\end{array}$ & 102 & 193.84 & & \\
\hline \multirow{2}{*}{$\begin{array}{l}\text { Level of self-esteem } \\
\text { Stopnja samospoštovanja }\end{array}$} & $\begin{array}{l}\text { No } \\
\text { ne }\end{array}$ & 287 & 194.58 & -0.269 & 0.788 \\
\hline & $\begin{array}{l}\text { Yes } \\
\text { da }\end{array}$ & 103 & 198.06 & & \\
\hline
\end{tabular}


No significant differences were found between the group with TEE and the group without TEE in their personality traits, coping styles and level of self-esteem.

However, the respondents with TEE differed significantly from their peers without TEE in the frequency of perception of their own reactions in adverse, stressful circumstances $\left(\chi^{2}(\mathrm{df}=2)=8.29, \mathrm{p}=0.016\right)$.; $62.4 \%$ of the respondents with TEE thought of themselves as being more powerful than they had expected; $9.3 \%$ of them found themselves more powerful and $28.1 \%$ reacted to stressful events as they would in situation with ordinary levels of stress. Perceiving themselves more powerful than they had expected was reported by $46.8 \%$ of respondents without TEE, less powerful $8.1 \%$ of them ; $44.6 \%$ of respondents reportedly reacted as they would in situations with ordinary stress levels.

\section{Discussion}

As the reported TEE is supposed to be such a strong stressor in the individual's personal history in any segment of the general population, we put forward some alternative hypotheses, assuming that significant differences will be found between the respondents who reported TEE and those without reported TEE. Contrary to these expectations, the hypotheses regarding gender differences were formulated as null hypotheses showing no significant differences. The number of deaths of significant others and the number of other recent and previous stressful events were significantly different between the respondents who did and those who did not report TEE; which means that respondents with TEE have also had to cope with a greater number of stressors. However, respondents, both those who did and those who did not report TEE have a similar jobrelated status; significant differences were found only for education obtained in the Army. A higher percentage of respondents reporting TEE obtained higher education while in the Army, which can be understood as an indirect indicator of healthy coping mechanisms of respondents reporting TEE. The female respondents reported TEE more frequently. In the general population, meta-analyses indicated that female participants were more likely than male participants to meet the criteria for PTSD, although they were less likely to experience a traumatic event (24).

Respondents with TEE more frequently reported a past history of depression, but did not differ from their peers without TEE in experience of current depression. Risky drinking of alcohol was found to be twice as frequent in respondents with TEE; however, the rate of risky drinking in respondents with TEE does not exceed the average estimate of risky drinkers in Slovenia, i.e.10\% (25). It is possible that respondents with TEE spoke more openly about their drinking habits than those without TEE. Compared to respondents who reported no TEE respondents with TEE are less likely to be smokers and more often report they had stopped smoking. The proportion of smokers among all respondents, however, was well above the Slovenian average, which is approximately $28 \%$ for adult men and $20 \%$ for adult women (25).

On the other hand, no significant gender differences were found when screening for risk of mental problems. The lack of a gender difference was expected in terms of alcohol abuse and smoking, but not in terms of the reported history of depression, neither present or past. As concerns childhood experiences, differences between men and women were found only for the item "very good experiences with adult outside family". This significant gender difference may be due to the fact that more boys than girls are members of child and adolescent sports clubs. On the other hand, respondents who did and those who did not report TEE differed in two instances of childhood experience: connecting behavioural problems in childhood and being especially talented as a child; respondents who had behavioural problems in childhood and those who identified themselves as talented in childhood had a higher frequency of TEE. This observation is very interesting also from the civilian point of view; gifted children tend to experience similar problems, such as behaviour difficulties, and talent is treated as a 'deviation'.

The picture obtained is in contrast to our expectations concerning TEE and perceived social support. Respondents with TEE seemed more likely to try and cope with stress alone. Social support was mainly found in intimate relationships (family, partner) rather than outside the family by all respondents. Female respondents were less likely to seek social support. We found no significant differences in personality traits, coping styles and level of self-esteem between the respondents who did and those who did not report TEE. However, the respondents with TEE significantly more often perceived themselves as more powerful in stressful circumstances than did their peers without TEE; which leads to a conclusion that they have a greater ability to rely on self in times of adversity. The respondents with TEE more frequently reported past depression, which is realistic to expect with regard to their trauma experience; yet they were also found to smoke less and to talk more openly about alcohol usage 
(which did not exceed the estimated national average of risky drinking). Trauma coping strategies of respondents with TEE can be considered effective with regard to the dependent variables of this study.

In the general population, men and women are found to have different attachment styles - women tending to rely on and value intimate social relationships more than men (26). Women also tend to have a higher incidence of anxious-depressive symptoms (27) and a lower incidence of alcohol (ab)use (28) and smoking (29). It seems that male and female military personnel tend to react similarly to stress; however, women less frequently seek social support in time of stress. It may be that female personnel try to prove their personal strength in times of adversity. Amongst war veterans, social support was the leading preventive factor against the development of PTSD (17); this is why seeking social support should not be stigmatized or labelled as weakness, but rather as a functional way of coping. The findings of a Slovenian study of occupational stress in Slovenian managers did not support the assumption that women experience a higher level of occupational stress than men; an observation consistent with our gender-related findings (30). However, in his study, Burke established significantly higher levels of occupational stress in women than in men (31). Maybe gender-related findings are influenced by the specific Slovenian cultural and normative context and should be further explored in future research.

The perceptions of Slovenian military personnel perceive their primary families as functional or "healthy"; this perception possibly enables them to form functional attachments in adult life. Intra-personal factors (personality, coping styles, and self-esteem) support the idea of good personal potential for the resilience of military personnel. There is a need for further research on stress management at the level of mental disorders, but also at the level of resilience factors; the findings seem to support the view that military personnel with TEE show considerable resilience, not only greater vulnerability. Special attention should be given to personnel who have experienced an accumulation of stressful events, who tend to be more vulnerable according to the literature (32). However, Slovenian military personnel are generally not inclined to seek professional help. Their attitude is consistent with the data in the literature: service members often refuse to disclose disturbing symptoms characteristic of PTSD, either due to their distrust of the mental health establishment or because they are too embarrassed to seek help (33).

The weaknesses of this research include: limited generalization of the results, permitting comparisons with similar samples only; research design, which was not conceptualized as an experimental or a quasiexperimental design, does not permit the interpretation of the results in the sense of influential factors. The distribution of results of the dependent variables differed significantly from the normal distribution and therefore did not allow for parametric univariate and multivariate analyses. It also appears that the category of trauma was not sufficiently diversified in terms of the perceived intensity and evaluated consequences. A dichotomized category of a "yes" and "no" answer to a question about traumatic experience could imply quite different degrees of such consequences, which do not contribute equally to supposed differences. As in any "paper-pencil « approach, self-written reports of trauma are not the same as those identified and evaluated during an interview conducted by experts, but could have the advantage of taking into account the subjective dimension of the phenomenon.

The main advantage of this research is the conceptualization of a problem that is relatively new in Slovenia: the psychosocial status of military personnel, especially related to trauma experience, is elaborated for the first time strictly with respect to the permitted use of statistical tools, and using a multi-aspect analysis of the phenomenon of trauma experience. It seems that the study could have an important applied value for the Slovenian army, especially for its psychological service. One of the directions for future research is to identify an early indication that a person may develop a mental disorder. Whilst realistic training may reduce the impact of operational duties upon mental health, it is nonsensical to argue that traumatic stress can ever be eliminated (34). Data on vulnerability and sources of resilience can empower leaders to implement management plans which may help create the best possible conditions for psychological recovery.

\section{References}

1. Rosengren A, Hawken S, Ounpuu S et al. Association of psychosocial risk factors with risk of acute myocardial infarction in 11119 cases and 13648 controls from 52 countries: case -control study. Lancet 2004; 364: 953 - 962.

2. Rose G, Bengtsson C, Dimberg L, Kumlin L, Eriksson B. Life events, mood, mental strain and cardiovascular risk factors in Swedish middle-aged men: data from the Swedish part of the Renault/Volvo Coeur Study. Occup Med (Lond) 1998; 48: 329-336.

3. Ozer EJ, Best SR, Lipsey TL, et al. Predictors of post-traumatic stress disorder and symptoms in adults: a meta-analysis. Psychol Bull 2003; 129: 52-73.

4. Maercker A, Mueller J. Social acknowledgement as a victim or survivor: a scale to measure a recovery factor of PTSD. J Trauma Stress 2004; 17: 345-351.

5. Gersons BPR, Olff M. Coping with the aftermath of trauma. BMJ 2005; 330: 1038-1039. 
6. Brewin CR, Andrews B, Valentine JD. Meta-analysis of risk factors for post-traumatic stress disorder in trauma-exposed adults. J Consult Clin Psychol 2000; 68: 748-766.

7. Mol SS, Arntz A, Metsemakers JF, et al. Symptoms of posttraumatic stress disorder after non-traumatic events: evidence from an open population study. Br J Psychiatry 2005; 186: 494499.

8. Lloyd DA. Cumulative adversity and post-traumatic stress disorder: evidence from a diverse community sample of young adults. Am J Orthopsychiatry 2004; 40: 381-391.

9. Norris FH. Impact of mass shooting on survivors, families, and communities. PTSD research Quaterly 2007; 18: 3-7.

10. Marshall RD, Olfson M, Hellman F, Blanco C, Guardino M, Struening EL. Comorbidity, impairment, and suicidality in subthreshold PTSD. Am J Psychiatry 2001; 158: 1467-1473.

11. Kessler RC, Sonnega A, Bromet E, Hughes M, Nelson CB. Posttraumatic stress disorder in the National comorbidity survey. Arch Gen Psychiatry 1995; 52: 1048-1060.

12. Hazen C, Shaver PR. Deeper into attachment theory. Psychol Inq 1994; 5: 68-80.

13. Diehl M, Elnick AB, Bourbeau LS, Labouvie G. Adult attachment styles: their relations to family context and personality. J Pers Soc Psychol 1998; 74: 1656-1669.

14. Renaud EF. The attachment characteristics of combat veterans with post-traumatic stress disorder. Traumatology 2008; 14: 1-12.

15. Dieperink M, Leskela J, Thuras-P, Engdahl B. Attachment style classification and post-traumatic stress disorder in former prisoners of war. Am J Orthopsychiatry 2001; 71: 374-378.

16. King DW, King LA, Foy DW, Gudanowski DM. Prewar factors in combat-related post-traumatic stress disorder: structural equation modeling with a national sample of female and male Vietnam veterans. J Consult Clin Psychol 1996; 64: 520-531.

17. King DW, King LA, Fairbank JA, Keane TM, Adams G. Resiliencerecovery factors in post-traumatic stress disorder among female and male Vietnam veterans: hardiness, postwar social support, and additional stressful life events. J Consult Clin Psychol 1998; 74: $420-434$.

18. Schnurr PP, Lunney CA, Sengupta A. Risk factors for the development versus maintenance of post-traumatic stress disorder. J Trauma Stress 2004; 17: 85-95.

19. Sheehan DV, Lecrubier $Y$, Sheehan $\mathrm{KH}$, Amorim $P$, Janavs J, Weiller E, Hergueta T, Baker R, Dunbar GC. The mini-international neuropsychiatric interview (M.I.N.I.); the development and validation of a structured diagnostic psychiatric interview for DSM-IV and ICD-10. J Clin Psychiat 1998; 59 (Suppl 20): 22-33.
20. Burge SK, Schneider FD. Alcohol-related problems: recognition and intervention. Am Fam Physician 1999; 59: 361-70.

21. Eysenck HJ, Eysenck SBG. Manual of the Eysenck personality questionnaire. London: Hodder and Stoughton, 1975.

22. Folkman S, Lazarus RS, Dunkel-Schetter C, DeLongis A, Gruen RJ. Dynamics of a stressful encounter: cognitive appraisal, coping, and encounter outcomes. J Pers Soc Psychol 1986; 50: 992-1003.

23. Rosenberg M. 1989. Society and the adolescent self-image. Revised ed. Middletown, CT: Wesleyan University Press, 1989.

24. Tolin DF, Foa EB. Sex differences in trauma and post-traumatic stress disorder: a quantitative review of 25 years of research. Psychol Bull 2006; 132: 959-992.

25. Zaletel-Kragelj L, Fras Z, Maučec-Zakotnik J. Tvegana vedenja, povezana z zdravjem in nekatera zdravstvena stanja pri odraslih prebivalcih Slovenije. Ljubljana: CINDI Slovenija, 2004.

26. Kirkpatrick LA, Davis KE. Attachment style, gender, and relationship stability: a longitudinal analysis. J Pers Soc Psychol 1994; 66: 502-512.

27. Kessing LV. Recurrence in affective disorder. II. Effect of age and gender Br J Psychiatry 1998; 172: 29-34.

28. Knibbe R, Bloomfield K. Alcohol consumption estimates in surveys in Europe: comparability and sensitivity for gender differences. Subst Abus 2001; 22: 23-38.

29. Kunze M, Groman E, Kunze U. Tobacco consumption and tobacco-related diseases: gender differences with a comparison between two European countries. J Men Health Gender 2004; 1: 83-87.

30. Meško M, Videmšek M, Karpljuk D, Meško Štok Z, Podbregar I. Occupational stress among Slovene managers with respect to their participation in recreational sport activities. Zdrav Var 2009; 49: 117-123.

31. Burke RJ. Organizational values, job experiences and satisfaction in managerial and professional women and men: advantage men? Women Manag Rev 2002; 17: 228-236.

32. Doruk A, Celik C, Ozdemir B, Ozsahin A. Adjustment disorder and life events. Anatolian J Psychiatry 2008; 9: 197-202.

33. Greenberg N, Langston V, Jones N. Trauma risk management (TriM) in the UK armed forces. JR Army Med Corps 2008; 154 : 124-127.

34. Greenberg N, Langston V, Scott R. How to TRIM Away at posttraumatic stress reactions: traumatic risk management - now and in the future. Available at: http://www.rta.nato.int/Pubs/RDP. asp?RDP=RTO-MP-HFM-134. 